\title{
The Effect of Exercise on Glucoregulatory Hormones: A Countermeasure to Human Aging: Insights from a Comprehensive Review of the Literature
}

\author{
Maha Sellami ${ }^{1, \dagger}$, Nicola Luigi Bragazzi ${ }^{2, *},+\left(\mathbb{D}\right.$, Maamer Slimani ${ }^{2} \mathbb{C}^{\text {, }}$ Lawrence Hayes $^{3}{ }^{\mathbb{D}}$, \\ Georges Jabbour ${ }^{1}$, Andrea De Giorgio ${ }^{4}$ and Benoit Dugué ${ }^{5}$ (i) \\ 1 Sport Science Program, College of Arts and Sciences (QU-CAS), University of Qatar, Doha 2713, Qatar; \\ msellami@qu.edu.qa (M.S.); gjabbour@qu.edu.qa (G.J.) \\ 2 Postgraduate School of Public Health, Department of Health Sciences (DISSAL), University of Genoa, \\ 16132 Genoa, Italy; maamer2011@hotmail.fr \\ 3 Active Ageing Research Group, Department of Medical and Sport Sciences, University of Cumbria, \\ Bowerham Road, Lancaster LA1 3JD, UK; lawrence.hayes@cumbria.ac.uk \\ 4 Department of Psychology, eCampus University, 22060 Novedrate, Italy; andrea.degiorgio@uniecampus.it \\ 5 Laboratory of Mobility, Aging and Exercise (MOVE), EA 6314 Poitiers, France; benoit.dugue@univ-poitiers.fr \\ * Correspondence: robertobragazzi@gmail.com; Tel.: +39-01-0353-8508 \\ + Contributed equally as first authors.
}

Received: 23 February 2019; Accepted: 11 May 2019; Published: 15 May 2019

check for updates

\begin{abstract}
Hormones are secreted in a circadian rhythm, but also follow larger-scale timetables, such as monthly (hormones of the menstrual cycle), seasonal (i.e., winter, summer), and, ultimately, lifespan-related patterns. Several contexts modulate their secretion, such as genetics, lifestyle, environment, diet, and exercise. They play significant roles in human physiology, influencing growth of muscle, bone, and regulating metabolism. Exercise training alters hormone secretion, depending on the frequency, duration, intensity, and mode of training which has an impact on the magnitude of the secretion. However, there remains ambiguity over the effects of exercise training on certain hormones such as glucoregulatory hormones in aging adults. With advancing age, there are many alterations with the endocrine system, which may ultimately alter human physiology. Some recent studies have reported an anti-aging effect of exercise training on the endocrine system and especially cortisol, growth hormone and insulin. As such, this review examines the effects of endurance, interval, resistance and combined training on hormones (i.e., at rest and after) exercise in older individuals. We summarize the influence of age on glucoregulatory hormones, the influence of exercise training, and where possible, examine masters' athletes' endocrinological profile.
\end{abstract}

Keywords: glucose; insulin; cortisol; growth hormone; physical activity; advanced age and senescence

\section{Introduction}

The aging process is accompanied by one or more changes in biological functions (affecting nervous system, cardiovascular and respiratory systems, or renal function, amongst others), often associated with an increasing susceptibility to co-morbidities and mortality $[1,2]$.

According to the World Health Organization (WHO), three categories of population can be distinguished: "young old" (65-74 years old), "middle aged" (75-84) and the oldest (85+). Generally, aging leads to an overall loss of tissue vitality through a myriad of signaling mechanisms [3].

The anatomical and physiological changes associated with aging start several years before the appearance of external signs. Many of these alterations gradually manifest in the third decade and continue until death. These changes are also accompanied by a gradual decline in physical fitness 
and physical activity. This alteration of the cardiovascular and respiratory systems during the aging process can be mainly explained by a decline in maximum oxygen uptake $(\sim 10 \%$ per decade) starting from the age of 20 [4-7].

Advancing age is also associated with a decline in anaerobic performance, which can be mainly explained by changes involving the neuromuscular system and a major loss in type II fibers. Indeed, advanced age is accompanied by muscular wasting, a decrease in the rate of contraction, and maximum force.

According to Korhonen et al. [8], the first decline in muscle strength and mass occurs around the age of 30 and the loss is around $15 \%$ per decade from the age of 50 to $30 \%$ at the age of 70 . Moreover, available scholarly literature suggests that starting from the 4th decade of life, both skeletal muscle mass and strength decline in a linear fashion and within the 8th decade of life, $50 \%$ of mass will be lost [9]. Since muscle mass amounts to $60 \%$ of body mass, its pathological changes can have deep consequences in the elderly.

One hypothesis for the reduction in physical performance and muscle weakness associated with age is an alteration of the endocrine system [10-14]. In particular, the glucoregulatory system that is characterized by important bio-molecules such as glucagon and insulin is critical to maintain the constancy of glucose in the internal milieu. While it is clear that exercise training improves fitness and physical capacity in older adults [15-19], whether exercise can improve the hormonal profiles of older adults remains contentious [20-27].

Therefore, this review will summarize the existing literature concerning the influence of age, and the effects of each mode of exercise (endurance, sprint, and resistance training) on relevant (basal) hormones belonging to the glucoregulatory system.

Where possible, we will provide evidence from masters athletes involving the influence of lifelong exercise on these hormones, but also report findings from interventional studies providing information on the training effect on these hormones.

\section{Materials and Methods}

The present review was designed as a comprehensive review of the literature. Search strategy adopted in the present review is summarized in Table 1.

Table 1. Search strategy adopted in the present comprehensive review of the literature for retrieving studies investigating the effects of physical activity and exercise on glucoregulatory hormones in elderly subjects.

\begin{tabular}{|c|c|}
\hline Search Strategy Item & Details \\
\hline Search string & $\begin{array}{c}\text { (old OR elderly OR effect of age OR aging OR ageing) AND (physical activity OR sport OR } \\
\text { exercise OR training) AND (insulin OR glucagon OR growth hormone OR IGF-1 OR } \\
\text { glucoregulatory hormones OR cortisol OR catecholamines) }\end{array}$ \\
\hline Searched databases & $\begin{array}{l}\text { PubMed/MEDLINE, Scopus, ISI/Web of Science } \\
\text { P (population): older subjects in good health }\end{array}$ \\
\hline Inclusion criteria & $\begin{array}{c}\text { I (intervention) / E (exposure): physical activity interventions; exposure to physical activity } \\
\text { C (comparator / comparison): young subjects (both trained and untrained) and old } \\
\text { untrained subjects }\end{array}$ \\
\hline & $\begin{array}{l}\mathrm{O} \text { (outcome): changes in glucoregulatory hormones levels } \\
\mathrm{S} \text { (study design): original, primary research article }\end{array}$ \\
\hline Exclusion criteria & $\begin{array}{l}\text { P (population): young subjects; old frail subjects or with diseases (diabetes, obesity) } \\
\text { I (intervention) / E (exposure): not exposed to physical activity / sports /exercise interventions or } \\
\text { exposed to combined interventions (dietary intervention, supplementation, pharmacological } \\
\text { treatment or other forms of manipulation) from which it was not possible to dissect the effect of } \\
\text { training only }\end{array}$ \\
\hline & $\begin{array}{l}\mathrm{C} \text { (comparator / comparison): absence of comparisons between age groups } \\
\text { O (outcome): changes in glucoregulatory hormone levels not reported in detail or not clear } \\
\text { S (study design): not original study (commentary, review, expert opinion, letter to editor, editorial) }\end{array}$ \\
\hline Time filter & None applied (from inception) \\
\hline Language filter & None applied (any language) \\
\hline
\end{tabular}




\section{Insulin, Aging and Physical Activity}

Insulin plays a key role in glucose uptake by muscle, fat, and liver cells. Moreover, insulin inhibits both the liver glucose production and its secretion in blood.

Recent reports suggest that the insulin/insulin-like growth factor-1 (IGF-1) signaling pathways and molecular cascades have an important, evolutionarily conserved influence over rate of aging and, thus, longevity [28]. The most important effects of advancing age on this hormone are the increase of fasting insulin and decrease in insulin sensitivity $[29,30]$.

Many studies examined the effect of different training modes, volumes and intensities on insulin levels in older adults. From the available investigations, it appears that short-term (two weeks) training was unable to reduce fasting insulin level in a group of 28 healthy middle-aged (40-55 years) sedentary men, as shown by Heiskanen and coauthors [31]. More in detail, a program of six supervised cycle ergometer training sessions, characterized either by high-intensity $(n=14 ; 4-6 \times 30$ s all-out cycling/4-min recovery) or continuous moderate-intensity ( $\mathrm{n}=14 ; 40-60 \mathrm{~min}$ at $60 \%$ peak $\mathrm{O}_{2}$ uptake) training did not affect fasting insulin concentration.

In contrast, Kirwan et al. [32] reported that nine months of endurance training reduced fasting insulin and improved insulin action. Seals and colleagues [33] (12 months of endurance training program), Kahn and coworkers [34] (six months of intensive endurance exercise program), Evans and coauthors [35] (10-12 months of endurance training program) reported similar results. Therefore, it appears that an intervention with a longer duration (e.g., from six up to 9-12 months) is required to observe significant changes in fasting insulin in older adults. On the other hand, some studies investigating the effects of 6/9-month training programs, such as the investigation by Goulet et al. [36], Dipietro and coworkers [37] or Ihalainen and collaborators [38] failed to report beneficial changes in insulin concentration.

The length of the training program seems to have an impact on insulin (in terms of levels or activity) depending on the age group in which the intervention is carried out. Herbert et al. [23] reported a moderate decrease in basal insulin following six weeks of high-intensity interval training (HIIT) in sedentary older males, suggesting that sprint training can reduce fasting insulin in older adults. Guezennec et al. [39,40] have investigated the impact of four months of weight lifting in athletes aged $\sim 35$ years old. After maximal sessions, the level of insulin did not change significantly.

Other studies examined the effect of resistance training in insulin sensitivity in elderly subjects and reported that strength training induced improvement in insulin-stimulated glucose uptake promoted by glucose transporter type 4 (GLUT-4) in elderly [41]. Further studies investigated the influence of 12 weeks of high resistance training (weight lifting program) in the elderly and observed decreased insulin response [42].

Furthermore, when comparing young and middle-aged men, Sellami et al. [43] investigated the impact of 13 weeks of combined sprint and strength training on insulin concentration in blood. They reported a significant decrease in fasting insulin in both groups. Interestingly, the effect of age that was evident at baseline was no longer present post-training, suggesting that combined sprint and strength training can prevent the negative effects of aging in trained men [43].

From a molecular standpoint, it seems that lifelong regular physical activity leads to epigenetic mechanisms in terms of global DNA methylation patterns positively impacting on skeletal muscles' functioning in aged healthy individuals. One study has recently found that DNA methylation was statistically significantly lower in 714 promoters of genes involved in glycogen metabolism, glycolysis, oxidative stress resistance and muscle contraction, activity and myogenesis, whereas, methylation of introns, exons and CpG islands was apparently independent of physical activity practice [38]. Other cellular mechanisms that can explain how exercise can mitigate the mandatory age-related change in insulin levels include GLUT expression and translocation, skeletal muscle capillarization, improving insulin activity and sensitivity and favoring glucose uptake [42,44-52].

Even if short-term training cannot affect insulin levels, it seems to be sufficient in improving or at least preserving insulin secretion pattern and response to oral glucose load. Some studies have, 
indeed, shown that a single bout of high intensity intermittent exercise [53], a couple of bouts of exercise [54,55] or light/moderate-intensity physical activity [56-60] can be sufficient in preserving insulin activity and response to oral glucose tolerance test (OGTT).

In other studies, the physical activity level (trained versus untrained) was self-reported and assessed through the administration of questionnaires [61-65] or via quantitative measurements, such as accelerometer [59]. Some studies included in the present comprehensive review were high-quality randomized or pseudo-randomized studies [66-68].

Summarizing (Table 2), based on the available studies, it appears that aging is associated with an increase of insulin level; a major part of this increase can be counteracted by exercise training. Exercise is, indeed, a full mediator of the relationship between inactivity time sedentary behaviors and insulin resistance [69]. Exercise, especially long-term (i.e., 12-24 weeks and not less than 8-10 weeks) [70-72] endurance, resistance and multimodal/combined training [73,74] or short-term (i.e., bouts of six weeks of HIIT) [75-77] training program, can positively impact on insulin levels [78], even though existing scholarly findings are not so clear-cut and warrant further investigations.

Table 2. Studies investigating the effects of physical activity and exercise on insulin in elderly subjects.

\begin{tabular}{|c|c|c|c|c|c|c|}
\hline Authors & Study Year & Sample Size & Age & Gender & Intervention & Main Findings \\
\hline Seals et al. [61] & 1984 & 11 & $63 \pm 1 y$ & $\begin{array}{l}\text { Male and } \\
\text { female }\end{array}$ & $\begin{array}{l}12 \text { months of endurance } \\
\text { training (low-versus } \\
\text { high-intensity program) }\end{array}$ & $\begin{array}{l}\text { Improved insulin sensitivity } \\
\text { and reduction in total AUC for } \\
\text { insulin by } 8-23 \% \text { (by } 8 \% \text { after } \\
\text { the low-intensity training } \\
\text { program and by } 23 \% \text { after the } \\
\text { high-intensity } \\
\text { training program) } \\
\text { Lean older subjects had similar } \\
\text { insulin levels when compared } \\
\text { to younger subjects and } \\
\text { statistically lower than the } \\
\text { older untrained individuals }\end{array}$ \\
\hline $\begin{array}{l}\text { Hollenbeck et al. } \\
\text { [62] }\end{array}$ & 1985 & $\begin{array}{l}20 \text { (13 inactive } \\
\text { versus } 7 \text { active } \\
\text { subjects) }\end{array}$ & $60-75 y$ & Male & $\begin{array}{l}\text { Self-reported physical } \\
\text { activity level }\end{array}$ & $\begin{array}{l}\text { Better insulin resistance profile } \\
\text { in older trained subjects }\end{array}$ \\
\hline Craig et al. [42] & 1989 & $\begin{array}{l}9 \text { (cases versus } 6 \\
\text { young controls) }\end{array}$ & $62.8 \pm 0.7 y$ & Male & $\begin{array}{l}12 \text { weeks of progressive } \\
\text { high-resistance training } \\
\text { (weight lifting program with a } \\
\text { three set, six to eight repetition } \\
\text { protocol: } 45-60 \text { min of isotonic } \\
\text { weight-conditioning exercise } \\
\text { on Nautilus equipment and leg } \\
\text { press, leg extension, leg curl, } \\
\text { torso extension, bench press, } \\
\text { pull down, pull over and } \\
\text { horizontal arm adduction) }\end{array}$ & Reduction in insulin levels \\
\hline Tonino [70] & 1989 & 11 & $60-80 y$ & Male & 12 weeks of physical training & $\begin{array}{l}\text { Decrease in peripheral insulin } \\
\text { resistance }\end{array}$ \\
\hline Kahn et al. [34] & 1990 & 13 & $61-82 y$ & Male & $\begin{array}{l}6 \text { months of intensive } \\
\text { endurance exercise training }\end{array}$ & $\begin{array}{c}\text { Decrease of insulin levels } \\
\text { Increase of insulin sensitivity } \\
\text { by } 36 \%\end{array}$ \\
\hline Broughton et al. [63] & 1991 & $\begin{array}{l}13 \text { (cases versus } 14 \\
\text { young controls) }\end{array}$ & $\begin{array}{l}60 \mathrm{y} \text { and } \\
\text { older }\end{array}$ & Male & $\begin{array}{l}\text { Self-reported physical } \\
\text { activity level }\end{array}$ & No significant differences \\
\hline $\begin{array}{l}\text { Poehlman and } \\
\text { Danforth [71] }\end{array}$ & 1991 & focom & $64 \pm 1.6 y$ & Male & $\begin{array}{l}8 \text { weeks of endurance training } \\
\text { program (cycling exercise) }\end{array}$ & No changes in insulin levels \\
\hline Kirwan et al. [32] & 1993 & 12 & $\begin{array}{l}65 \pm 1 \mathrm{y} \\
{[60-70 \mathrm{y}]}\end{array}$ & Male & 9 months of endurance training & $\begin{array}{l}\text { Reduction in fasting insulin } \\
\text { Improved insulin activity } \\
\text { Fasting plasma insulin levels }\end{array}$ \\
\hline Cononie et al. [75] & 1994 & 9 & $60-80 y$ & Male & $\begin{array}{l}\text { Seven days of } 50 \mathrm{~min} \text { of } \\
\text { exercise at } 70 \% \mathrm{VO}_{2 \max }\end{array}$ & $\begin{array}{l}\text { Fasting plasma insulin levels } \\
\text { and plasma insulin responses } \\
\text { to an oral glucose challenge } \\
\text { were reduced by } 15 \% \text { and } 20 \%\end{array}$ \\
\hline DiPietro et al. [60] & 1998 & $\begin{array}{c}16 \text { ( } 7 \text { of which } \\
\text { serving as controls) }\end{array}$ & $73 \pm 1 y$ & $\begin{array}{l}\text { Male and } \\
\text { female }\end{array}$ & $\begin{array}{l}\text { Moderate-intensity aerobic } \\
\text { training, four times a week for } \\
60 \text {-min sessions }\end{array}$ & $\begin{array}{l}\text { Improvement in insulin } \\
\text { resistance and glucose } \\
\text { tolerance }\end{array}$ \\
\hline Chadan et al. [54] & 1999 & 7 & $62-69 y$ & Female & $\begin{array}{l}\text { Four bouts of physical activity } \\
\text { on separate occasions at either } \\
\text { a low (heart rate }=100 \mathrm{bpm} \text { ) or } \\
\text { moderate intensity (heart rate }= \\
120 \mathrm{bpm} \text { ) for either } 25 \text { or } 50 \mathrm{~min}\end{array}$ & $\begin{array}{l}\text { Decrease by } 35 \% \text { in all } \\
\text { experimental conditions }\end{array}$ \\
\hline Evans et al. [35] & 2005 & 10 & $\begin{array}{c}80.3 \pm 2.5 \mathrm{y} \\
77-87 \mathrm{y}\end{array}$ & $\begin{array}{l}\text { Male }(\mathrm{n}=8) \\
\text { and female } \\
\quad(\mathrm{n}=2)\end{array}$ & $\begin{array}{c}10-12 \text { months of program (for a } \\
\text { total of } 108 \text { exercise sessions) } \\
\text { consisting in a supervised } \\
\text { endurance exercise training } \\
\text { comprising of } 2.5 \\
\text { sessions/week, } 58 \text { min/session, } \\
\text { at an intensity of } 83 \% \text { of peak } \\
\text { heart rate }\end{array}$ & Improvement in insulin activity \\
\hline Goulet et al. [36] & 2005 & $\begin{array}{l}8 \text { versus } 14 \text { younger } \\
\text { controls }\end{array}$ & $62.3 \pm 4.7 \mathrm{y}$ & Female & $\begin{array}{l}\text { Aerobic training ( } 25-60 \mathrm{~min} \\
\text { sessions of running at } 60-95 \% \\
\text { of maximal heart rate) three } \\
\text { days per week during } \\
6 \text { months, with insulin } \\
\text { resistance measured 3-5 days } \\
\text { after the last training bout }\end{array}$ & $\begin{array}{l}\text { No improvement in insulin } \\
\text { resistance }\end{array}$ \\
\hline
\end{tabular}


Table 2. Cont.

\begin{tabular}{|c|c|c|c|c|c|c|}
\hline Authors & Study Year & Sample Size & Age & Gender & Intervention & Main Findings \\
\hline DiPietro et al. [66] & 2006 & 25 & $73 \pm 10 y$ & Female & $\begin{array}{c}\text { Random allocation to } \\
\text { high-intensity }[80 \% \text { peak } \\
\left.\text { aerobic capacity }\left(\mathrm{VO}_{2 \text { peak }}\right)\right] \\
\text { aerobic training, } \\
\text { moderate-intensity }(65 \% \\
\mathrm{VO}_{2 \text { peak }} \text { ) aerobic training, and } \\
\text { low-intensity (stretching) } \\
\text { placebo control }\left(50 \% \mathrm{VO}_{2 \text { peak }}\right) \\
\text { groups }\end{array}$ & $\begin{array}{l}\text { Significant improvements only } \\
\text { in the high-intensity } \\
\text { training group }\end{array}$ \\
\hline Bassami et al. [76] & 2007 & 13 & $\begin{array}{l}60 \mathrm{y} \text { and } \\
\text { older }\end{array}$ & Male & $\begin{array}{l}\text { Three } 30-\mathrm{min} \text { trials on a cycle } \\
\text { ergometer at } 50 \%, 60 \% \text { and } 70 \% \\
\mathrm{VO}_{2 \max } \text { and two other trials at } \\
60 \% \text { and } 70 \% \mathrm{VO}_{2 \max } \text { in which } \\
\text { the total energy expenditure } \\
\text { was equal to that for } 30 \mathrm{~min} \text { at } \\
50 \% \mathrm{VO}_{2}\end{array}$ & $\begin{array}{l}\text { No significant differences } \\
\text { between groups }\end{array}$ \\
\hline Fujita et al. [55] & 2007 & 13 & $70 \pm 2 y$ & $\begin{array}{l}\text { Male }(\mathrm{n}=10) \\
\text { and female } \\
\quad(\mathrm{n}=3)\end{array}$ & $\begin{array}{c}\text { Bout of aerobic exercise (45-min } \\
\text { treadmill walk, } 70 \% \text { heart } \\
\text { rate max) }\end{array}$ & $\begin{array}{l}\text { Improvement in } \\
\text { insulin resistance }\end{array}$ \\
\hline Kodama et al. [56] & 2007 & 56 & $64 \pm 6 y$ & $\begin{array}{l}\text { Male }(\mathrm{n}=14) \\
\text { and female } \\
\quad(\mathrm{n}=42)\end{array}$ & $\begin{array}{l}\text { Low-intensity and low-volume } \\
\text { exercise training (12-week } \\
\text { exercise program, comprising } \\
\text { of aerobic training and } \\
\text { resistance training) }\end{array}$ & $\begin{array}{l}\text { Decrease in insulin resistance } \\
\text { by } 21 \%\end{array}$ \\
\hline Dipietro et al. [37] & 2008 & 20 & $74 \pm 5 y$ & Female & $\begin{array}{c}\text { Random allocation into } \\
\text { a high-volume, } \\
\text { moderate-intensity aerobic } \\
(\mathrm{n}=12) \text { and a lower-intensity } \\
\text { resistance training }(\mathrm{n}=8) \\
\text { groups } 4 \text { times per week for } 45 \\
\text { to } 60 \text {-min sessions over } \\
\text { nine months }\end{array}$ & $\begin{array}{c}\text { Not statistically significant } \\
\text { changes in insulin levels in } \\
\text { both groups }\end{array}$ \\
\hline Dela et al. [72] & 2011 & $\begin{array}{c}42 \text { (20 of which } \\
\text { serving as controls) }\end{array}$ & $\begin{array}{l}60 \mathrm{y} \text { and } \\
\text { older }\end{array}$ & $\begin{array}{l}\text { Male and } \\
\text { female }\end{array}$ & 12 weeks of alpine ski training & $\begin{array}{l}\text { Decrease in insulin } \\
\text { concentration, decreased } \\
\text { insulin resistance }\end{array}$ \\
\hline Lira et al. [57] & 2011 & 14 & $\begin{array}{l}70.32 \pm 0.72 \\
y\end{array}$ & Male & $\begin{array}{l}\text { Moderate training for } 60 \mathrm{~min} / \mathrm{d} \text {, } \\
3 \text { day/w for } 24 \text { weeks at a work } \\
\text { rate equivalent to the } \\
\text { ventilatory aerobic threshold }\end{array}$ & $\begin{array}{l}\text { Improvement in insulin } \\
\text { concentration and } \\
\text { insulin resistance }\end{array}$ \\
\hline Mikkelsen et al. [64] & 2013 & $\begin{array}{l}27 \text { versus } 22 \text { young } \\
\text { controls }\end{array}$ & NR & Male & $\begin{array}{l}\text { Self-reported physical activity } \\
\qquad(\mathrm{n}=15 \text { trained, } \\
\mathrm{n}=12 \text { untrained })\end{array}$ & $\begin{array}{l}\text { Better insulin profile in } \\
\text { trained subjects }\end{array}$ \\
\hline Gando et al. [59] & 2014 & 807 & $58-59 \mathrm{y}$ & $\begin{array}{l}\text { Male and } \\
\text { female }\end{array}$ & $\begin{array}{l}\text { Physical activity was measured } \\
\text { using a triaxial accelerometer } \\
\text { worn for } 28 \text { days and } \\
\text { summarized as light intensity } \\
\text { (1.1-2.9 METs) or moderate to } \\
\text { vigorous intensity ( } \geq 3.0 \text { METs) }\end{array}$ & $\begin{array}{l}\text { Light physical activity } \\
\text { inversely associated with } \\
\text { insulin resistance }\end{array}$ \\
\hline Hwang et al. [67] & 2016 & $\begin{array}{l}51 \text { (16 of which } \\
\text { serving as controls) }\end{array}$ & $\begin{array}{l}65 \pm 1 \mathrm{y} \\
{[55-79 \mathrm{y}]}\end{array}$ & $\begin{array}{l}\text { Male and } \\
\text { female }\end{array}$ & $\begin{array}{l}\text { Randomly allocated to } \\
\text { high-intensity interval training } \\
(\mathrm{n}=17) \text { or to moderate } \\
\text { intensity continuous training } \\
(\mathrm{n}=18)\end{array}$ & $\begin{array}{l}\text { Insulin resistance decreased by } \\
26 \% \text { only in the high-intensity } \\
\text { interval training group }\end{array}$ \\
\hline Herbert et al. [23] & 2017 & $\begin{array}{l}22 \text { (cases) versus } 17 \\
\text { (controls) }\end{array}$ & $62 \pm 2 y$ & Male & $\begin{array}{l}\text { Randomly allocated to the } \\
\text { eccentric training or concentric } \\
\text { training group ( } \mathrm{n}=13 \text { per } \\
\text { group), performing } 30-60 \\
\text { eccentric or concentric } \\
\text { contractions of knee extensors } \\
\text { once a week. The intensity of } \\
\text { the training program was } \\
\text { progressively increased over a } \\
\text { period of } 12 \text {-weeks from } 10 \% \text { to } \\
100 \% \text { of maximal concentric } \\
\text { strength for eccentric training } \\
\text { and from } 50 \% \text { to } 100 \% \text { for the } \\
\text { concentric training program } \\
6 \text { weeks of high-intensity } \\
\text { interval training }\end{array}$ & $\begin{array}{l}\text { Statistically significant } \\
\text { improvement of insulin } \\
\text { sensitivity only after } \\
\text { eccentric training }\end{array}$ \\
\hline Robinson et al. [73] & 2017 & 26 & $\begin{array}{l}60 \mathrm{y} \text { and } \\
\text { older }\end{array}$ & Male $(53.8 \%)$ & $\begin{array}{l}12 \text { weeks of high-intensity } \\
\text { aerobic interval, resistance, and } \\
\text { combined exercise training }\end{array}$ & $\begin{array}{l}\text { Increased insulin activity and } \\
\text { sensitivity, with effects more } \\
\text { marked in the high-intensity } \\
\text { aerobic interval group }\end{array}$ \\
\hline Banitalebi et al. [74] & 2018 & $\begin{array}{l}40 \text { (12 of which } \\
\text { serving as controls) }\end{array}$ & $\begin{array}{c}67.35 \pm 1.40 \\
y\end{array}$ & Female & $\begin{array}{l}\text { Randomly allocated to a } \\
\text { resistance followed by } \\
\text { endurance training program } \\
(\mathrm{n}=12) \text {, endurance training } \\
\text { followed by resistance training } \\
(\mathrm{n}=12) \text {, interval } \\
\text { resistance-endurance training } \\
\qquad(\mathrm{n}=12)\end{array}$ & $\begin{array}{l}\text { No differences among the } \\
\text { groups and no difference } \\
\text { between before and after } \\
\text { the intervention }\end{array}$ \\
\hline $\begin{array}{l}\text { Lithgow and } \\
\text { Leggate [53] }\end{array}$ & 2018 & 14 & $64 \pm 2 y$ & $\begin{array}{l}\text { Male and } \\
\text { female }\end{array}$ & $\begin{array}{l}\text { Single bout of high intensity } \\
\text { intermittent exercise }\end{array}$ & $\begin{array}{l}\text { Insulin concentration during an } \\
\text { OGTT elevated at } 60 \text { min when } \\
\text { compared to the control trial }\end{array}$ \\
\hline McGregor et al. [58] & 2018 & 1,454 & $65-79$ y & $\begin{array}{l}\text { Male and } \\
\text { female }\end{array}$ & $\begin{array}{l}\text { Light-intensity physical activity } \\
\text { and moderate to vigorous } \\
\text { intensity physical activity } \\
\text { assessed during the Canadian } \\
\text { Health Measures Survey }\end{array}$ & $\begin{array}{c}2,000 \text { steps } / \mathrm{d} \text { can be sufficient } \\
\text { to preserve insulin activity } \\
\text { and sensitivity }\end{array}$ \\
\hline Park et al. [65] & 2018 & 2,325 & $60-74 \mathrm{y}$ & $\begin{array}{c}\text { Male } \\
(\mathrm{n}=862) \\
\text { and female } \\
(\mathrm{n}=1,463)\end{array}$ & $\begin{array}{l}\text { Self-reported physical } \\
\text { activity level }\end{array}$ & $\begin{array}{l}\text { OR of developing insulin } \\
\text { resistance } 0.55[95 \% \mathrm{CI} \\
0.34-0.87] \text { in men and } 0.68 \\
{[95 \% \mathrm{CI} 0.47-0.98 \text { in women }}\end{array}$ \\
\hline Søgaard et al. [77] & 2018 & 22 & $63 \pm 1 y$ & $\begin{array}{c}\text { Male }(\mathrm{n}=11) \\
\text { and female } \\
(\mathrm{n}=11)\end{array}$ & $\begin{array}{l}\text { High-intensity interval training } \\
\text { three times/w for } 6 \text { weeks on a } \\
\text { bicycle ergometer }\end{array}$ & $\begin{array}{l}\text { Statistically significant } \\
\text { improved insulin sensitivity }\end{array}$ \\
\hline
\end{tabular}


Table 2. Cont.

\begin{tabular}{ccccccc}
\hline Authors & Study Year & Sample Size & Age & Gender & Intervention & Main Findings \\
\hline Thalainen et al. [38] 2019 & $\begin{array}{c}92 \text { randomly } \\
\text { assigned to a group } \\
\text { performing strength } \\
\text { training one-, two-, } \\
\text { or three-times-per-w } \\
\text { and a non-training } \\
\text { control group }\end{array}$ & 65-75y & $\begin{array}{c}\text { Male and } \\
\text { female }\end{array}$ & $\begin{array}{c}\text { Whole-body strength training } \\
\text { using 2-5 sets and 4-12 } \\
\text { repetitions per exercise and 7-9 } \\
\text { exercises per session for 6 mo }\end{array}$ & $\begin{array}{c}\text { No differences between groups } \\
\text { and between before and after } \\
\text { the intervention }\end{array}$ \\
\hline
\end{tabular}

Abbreviations: AUC (area under the curve); CI (confidence interval); d (day); MET (metabolic equivalent task); min (minute); mo (month); NR (not reported); OGTT (oral glucose tolerance test); OR (odds-ratio); w (week); y (years).

\section{IGF-1, Aging and Physical Activity}

The IGF1 gene is situated on the long arm of chromosome 12. IGF-I is an endocrine and autocrine/paracrine growth factor expressed by multiple cell types. It plays a key role in the growth of cells, muscle, cartilage, bone, skin, and controls cell growth. The concentration of IGF-1 in blood peaks around adolescence and then declines after middle-age. This reduction in anabolic hormones has been termed the 'somatopause', and is suggested as a mechanism for the process of aging.

Importantly, IGF-1 is implicated in skeletal and muscle function, which deteriorates with age. Eight weeks' endurance training increased systemic IGF-1 in 66-year-old males by 19\% [79].

However, other studies failed to observe any change in IGF-I following six months' endurance training in 67-year-old males. Herbert et al. [23] investigated the difference between endurance-trained master athletes ( $\sim 60$ years) and lifelong sedentary older adults ( $\sim 62$ years) and observed greater serum IGF-1 concentration in the trained compared to the sedentary subjects $(\sim 18.4 \mathrm{vs} . \sim 13.1 \mu \mathrm{g} / \mathrm{dL}$, respectively). Moreover, when exposing sedentary individuals to an endurance training program of $150 \mathrm{~min} /$ week, there was a small, non-significant increase in IGF-1 ( $8 \%$ increase).

In addition, few studies explored the influence of sprint training on IGF-1 in older adults. Herbert et al. [23] observed that old ( 62 years) sedentary subjects experienced a large increase in IGF-1 following 12 weeks' preconditioning and HIIT ( $\sim 13.1$ to $\sim 16.9 \mu \mathrm{g} / \mathrm{dL})$. Although six weeks of preconditioning of $150 \mathrm{~min} /$ week accounted for $8 \%$ of the change in IGF-1, HIIT was responsible for a further $21 \%$ increase ( $28 \%$ greater than baseline). Findings from the same study suggest a trivial change in IGF-1 post-HIIT in age-matched master athletes. Therefore, post-HIIT, the sedentary individuals and master athletes had IGF-1 concentrations that were not significantly different.

Furthermore, when looking at the alteration of IGF-1 after resistance training in older adults, Parkhouse et al. [80] observed an increase in 68 year old females' circulating IGF-1. However, a recent investigation reported decreased systemic IGF-1 following 12 weeks' resistance training in older adults (74 \pm 6 years) with an increase in lean mass [81].

As such, Arnason et al. [81] hypothesized that IGF-I was redistributed from circulation into tissue during periods of anabolism. As a result of the ambiguity in the findings, the role of IGF-I in the adaptive process to exercise during middle and older age remains unclear. The majority of studies reported that resistance training can increase the concentration of IGF-1 in blood and increase muscle mass and function [82-97]. Yet, more longitudinal studies are needed to explore the influence of resistance training on IGF-1 in older adults, given the presence of discrepancies among the findings.

In a recent study, Sellami et al. [43] investigated the influence of age on somatotropic hormones. They observed that young males had greater serum IGF-1 concentration than middle-aged men. Moreover, Sellami et al. [43] reported that 13 weeks of combined sprint and resistance training increased circulating IGF-1 in middle-aged participants. Furthermore, the effect of age that was apparent at the study commencement was abrogated post-training, suggesting that exercise can counteract the effect of age on IGF-1 in middle-aged men.

Taken together (Table 3), these data suggest that HIIT, resistance and combined training may be a countermeasure to the age and lifestyle-related reduction in IGF-1, activating some gene pathways and protein cascades $[98,99]$. 
Table 3. Studies investigating the effects of physical activity and exercise on IGF-1 in elderly subjects.

\begin{tabular}{|c|c|c|c|c|c|c|}
\hline Authors & Study Year & Sample Size & Age & Gender & Intervention & Main findings \\
\hline Hagberg et al. [82] & 1985 & $\begin{array}{l}10 \text { (cases versus } 11 \text { young } \\
\text { trained subjects, } 13 \text { young } \\
\text { sedentary subjects and } \\
11 \text { old trained subjects) }\end{array}$ & $60-70 y$ & Male & $\begin{array}{l}\text { Progressive } \mathrm{VO}_{2 \max } \text { test and } \\
\text { modified Balke protocol }\end{array}$ & No changes \\
\hline $\begin{array}{l}\text { Poehlman and } \\
\text { Copeland [83] }\end{array}$ & 1990 & $\begin{array}{l}26 \text { (cases versus } 42 \\
\text { young controls) }\end{array}$ & $59-76$ & Male & $\begin{array}{l}\text { Self-reported physical } \\
\text { activity level }\end{array}$ & $\begin{array}{l}\text { IGF-1 level correlating with } \\
\text { leisure time physical activity } \\
(\mathrm{r}=0.45 ; p<0.01)\end{array}$ \\
\hline Poehlman et al. [84] & 1994 & 18 & $66.1 \pm 1.4 y$ & $\begin{array}{l}\text { Male }(\mathrm{n}=10) \\
\text { and female } \\
\quad(\mathrm{n}=8)\end{array}$ & 8 weeks of endurance training & Increase in IGF-1 level by $14 \%$ \\
\hline Vitiello et al. [85] & 1997 & 67 & $\begin{array}{l}60 \mathrm{y} \text { and } \\
\text { older }\end{array}$ & $\begin{array}{l}\text { Male }(\mathrm{n}=46) \\
\text { and female } \\
\quad(\mathrm{n}=21)\end{array}$ & $\begin{array}{l}\text { Randomized allocation to } \\
3 \mathrm{~d} / \mathrm{w}, 6 \text {-months endurance, } \\
\text { stretching/flexibility groups } \\
\text { and to } 5 \text {-d/w, 6-months } \\
\text { endurance protocol }\end{array}$ & $\begin{array}{l}\text { No differences among the } \\
\text { different experimental groups } \\
\text { and between before and after } \\
\text { the exercise interventions }\end{array}$ \\
\hline Bermon et al. [86] & 1999 & 32 & $67-80 y$ & $\begin{array}{l}\text { Male }(\mathrm{n}=16) \\
\text { and female } \\
\quad(\mathrm{n}=16)\end{array}$ & $\begin{array}{l}\text { Randomly allocated to habitual } \\
\text { physical activity or to an } \\
\text { 8-week strength } \\
\text { training program }\end{array}$ & $\begin{array}{l}\text { Increase in total and free IGF-1 } \\
\text { levels immediately after } \\
\text { exercise (by } 17.7 \% \text { and } 93.8 \% \text { ) } \\
\text { and at } 6 \text { hours after exercise } \\
\text { (by } 7.5 \% \text { and } 31.2 \% \text { ) }\end{array}$ \\
\hline Bonnefoy et al. [87] & 1999 & 39 & $66-84$ y & $\begin{array}{l}\text { Male }(\mathrm{n}=14) \\
\text { and female } \\
\quad(\mathrm{n}=25)\end{array}$ & $\begin{array}{l}\text { Acute and chronic exercise (in a } \\
\text { period of } 6 \text { months) evaluated } \\
\text { using a self-administered } \\
\text { questionnaire }\end{array}$ & $\begin{array}{l}\text { IGF-1 levels correlated with } \\
\text { sports activity }\end{array}$ \\
\hline Chadan et al. [54] & 1999 & 7 & $62-69 y$ & Female & $\begin{array}{l}\text { Four bouts of physical activity } \\
\text { on separate occasions at either } \\
\text { a low (heart rate }=100 \mathrm{bpm} \text { ) or } \\
\text { moderate intensity (heart rate = } \\
120 \mathrm{bpm} \text { ) for either } 25 \text { or } 50 \text { min }\end{array}$ & $\begin{array}{l}\text { No differences among the } \\
\text { different experimental } \\
\text { conditions }\end{array}$ \\
\hline Ravaglia et al. [88] & 2001 & 48 & $\begin{array}{l}60 \mathrm{y} \text { and } \\
\text { older }\end{array}$ & Male & $\begin{array}{l}\text { Self-reported physical activity: } \\
\text { active }(\mathrm{n}=24) \text { and inactive } \\
\qquad(\mathrm{n}=24)\end{array}$ & $\begin{array}{l}\text { Higher IGF- } 1 \text { levels in } \\
\text { active men }\end{array}$ \\
\hline Borst et al. [89] & 2002 & 62 & $68.1 \mathrm{y}$ & $\begin{array}{l}\text { Male and } \\
\text { female }\end{array}$ & $\begin{array}{l}\text { Randomly allocated to } \\
\text { 6-month, 3-d/w program of } \\
\text { low-intensity or high-intensity } \\
\text { resistance training programs }\end{array}$ & No changes \\
\hline Dennis et al. [90] & 2008 & 16 versus 15 young controls & $72 \pm 5 y$ & Male & Acute resistance exercise & $\begin{array}{l}\text { Higher levels of IGF-1 and } \\
\text { IGFBP5 in younger subjects, } \\
\text { especially after acute } \\
\text { resistance exercise }\end{array}$ \\
\hline Tsai et al. [91] & 2015 & $\begin{array}{l}48 \text { (24 of which serving } \\
\text { as controls) }\end{array}$ & $\begin{array}{l}71.40 \pm 3.79 \\
\mathrm{y}(65-79 \mathrm{y})\end{array}$ & Male & Long-term resistance exercise & Increase in IGF-1 levels \\
\hline Maass et al. [92] & 2016 & asentiof & $60-77$ & Male & $\begin{array}{l}\text { Pseudo-random allocation to } \\
\text { aerobic exercise group (indoor } \\
\text { treadmill, } n=21 \text { ) or to a control } \\
\text { group (indoor } \\
\text { progressive-muscle } \\
\text { relaxation/stretching, } n=19 \text { ) }\end{array}$ & No changes \\
\hline $\begin{array}{l}\text { De Gonzalo-Calvo } \\
\text { et al. [93] }\end{array}$ & 2012 & $\begin{array}{c}26 \text { (active, } \mathrm{n}=13 \text {, inactive, } \\
\mathrm{n}=13 \text { ) }\end{array}$ & $\begin{array}{l}65 \mathrm{y} \text { and } \\
\text { older }\end{array}$ & Male & $49 \pm 8$ y of long-life training & $\begin{array}{l}\text { Increase in IGF-1 concentration } \\
\text { correlating with } \\
\text { physical activity }\end{array}$ \\
\hline Arnarson et al. [81] & 2015 & 235 & $73.7 \pm 5.7 y$ & $\begin{array}{l}\text { Male }(41.8 \%) \\
\text { and female } \\
\quad(58.2 \%)\end{array}$ & $\begin{array}{l}\text { 12-week resistance exercise } \\
\text { program ( } 3 \text { times/w; } 3 \text { sets, 6-8 } \\
\text { repetitions at } 75-80 \% \text { of the } \\
\text { 1-repetition maximum) }\end{array}$ & Decrease in IGF-1 levels \\
\hline Herbert et al. [23] & 2017 & $\begin{array}{l}22 \text { (cases) versus } 17 \\
\text { (controls) }\end{array}$ & $62 \pm 2 y$ & Male & $\begin{array}{l}12 \text { weeks of preconditioning } \\
\text { and } 6 \text { weeks of } \\
\text { high-intensity training }\end{array}$ & $\begin{array}{l}\text { Increase compared to baseline, } \\
\text { and compared to } \\
\text { preconditioning } \\
\text { Preconditioning accounted for } \\
8 \% \text { of the increase from baseline }\end{array}$ \\
\hline Negaresh et al. [94] & 2017 & $\begin{array}{l}15 \text { versus } 16 \text { younger } \\
\text { controls }\end{array}$ & $\begin{array}{l}60 \mathrm{y} \text { and } \\
\text { older }\end{array}$ & Male & 8 weeks of resistance training & $\begin{array}{c}\text { No change in IGF-1 levels } \\
\text { after training }\end{array}$ \\
\hline Yoon et al. [95] & 2017 & 21 & $65-75$ y & Female & $\begin{array}{l}\text { Randomly allocated to a } \\
\text { low-intensity resistance } \\
\text { training with heating sheet } \\
\text { group }(\mathrm{n}=8) \text {, a } \\
\text { moderate-intensity resistance } \\
\text { training }(\mathrm{n}=6) \text {, and a heating } \\
\text { sheet group }(\mathrm{n}=7) \text {, over } \\
12 \text { weeks }\end{array}$ & Increased IGF-1 level \\
\hline Banitalebi et al. [74] & 2018 & 40 & $\begin{array}{c}67.35 \pm 1.40 \\
y\end{array}$ & Female & $\begin{array}{l}\text { Randomized allocation to a } \\
\text { resistance followed by } \\
\text { endurance training }(\mathrm{n}=12) \\
\text { endurance training followed by } \\
\text { resistance training }(\mathrm{n}=12, \\
\text { interval resistance-endurance } \\
\text { training }(\mathrm{n}=12) \text { and a control } \\
(\mathrm{n}=12) \text { groups }\end{array}$ & $\begin{array}{l}\text { No differences among the } \\
\text { groups and no difference } \\
\text { between before and after } \\
\text { the intervention }\end{array}$ \\
\hline Cunha et al. [96] & 2018 & $\begin{array}{c}62 \text { (21 of which serving as } \\
\text { controls) }\end{array}$ & $\begin{array}{l}60 \mathrm{y} \text { and } \\
\text { older }\end{array}$ & Female & $\begin{array}{l}\text { Randomized allocation to a } \\
\text { single set resistance training ( } \mathrm{n} \\
=21) \text { or multiple set resistance } \\
\text { training }(\mathrm{n}=20 \text { ) programs, for } \\
12 \text { weeks using } 8 \text { exercises of } \\
10-15 \text { repetitions maximum for } \\
\text { each exercise }\end{array}$ & $\begin{array}{l}\text { Increase in IGF-1 levels (by } \\
7.1 \% \text { in the single set resistance } \\
\text { training group and by } 10.1 \% \text { in } \\
\text { the multiple set resistance } \\
\text { training group) }\end{array}$ \\
\hline Negaresh et al. [97] & 2019 & 15 & $55-70 \mathrm{y}$ & Male & $\begin{array}{l}\text { Whole-body progressive } \\
\text { resistance training program } 3 \\
\text { d/w for } 8 \text { weeks }(24 \text { sessions) }\end{array}$ & Increase in IGF-1 levels \\
\hline
\end{tabular}

Abbreviations: d (day); mo (month); w (week); y (years). 


\section{Growth Hormone, Aging and Physical Activity}

Growth hormone (GH) secretion decreases with age, resulting in a downstream reduction in IGF-1 levels. This change, termed as the somatopause, is associated with loss of vitality, muscle mass, physical function, and an increased risk of frailty, cardiovascular disease, and adiposity, amongst others [100].

Veldhuis et al. [101] showed that GH secretion during puberty varied between 1-1.5 mg/day, while elderly people can produce only $50 \mu \mathrm{g} /$ day. Several factors may be responsible for this decline, such as physical inactivity, poor nutrition, and subsequent changes in body composition. Moreover, Khan et al. [102] found that GH pulse decreased, and this decline was related to the alteration of hypothalamic and somatostatin hormones.

Moreover, GH has a beneficial neuroprotective effect [103] mainly due to the activation of anti-apoptotic pathway [104], this one particularly studied in literature. GH is also able to act on brain derived neurotrophic factor (BDNF) and neurotrophin-3 (NT3) [103] which, in turn, are particularly sensitive to physical activity.

Until now, there have been no studies that have explored the impact of endurance training on GH in older adults. Deuschle et al. [105] studied 11 elderly male marathon runners compared to 10 age-matched male sedentary people (controls), in order to study plasma concentration of GH, total and free IGF-I/II and IGF-binding protein-1, 2, and 3 and insulin. In particular, authors did not find any differences between runner vs controls, except for IGF-binding protein-1 and 2 increased in runners.

Moreover, Vanhelder al. [106] found similar results with a group of men aged 24-54 years who participated in resistance training for one year. The program was composed of two exercises (exercise protocol 1: vertical leg lifts at $85 \%$ of the subjects seven repetition maximum (SRM)/exercise protocol 2: vertical leg lifts with one third of the previously used load). The results showed that GH increased immediately after 5, 10, 25 min of exercise protocol 1 . However, there was no significant increase after exercise protocol 2. These findings suggest that the frequency, duration of exercise play an important role in the regulation of GH secretion. Generally, the available studies showed that the frequency and intensity of resistance training are important factors in the regulation of GH secretion.

Recently, Sellami et al. [43] reported that younger adults had greater $\mathrm{GH}$ at rest and in response to sprint exercise than middle-aged participants. However, 13 weeks of combined sprint and resistance training abrogated this age effect and increased GH at rest and post-exercise in both young and middle-aged participants.

Summarizing (Table 4), very few studies have investigated the effect of physical activity and training on GH levels in elderly subjects $[74,107,108]$, generally reporting negative findings. Further studies are needed to elucidate the mechanism of exercise on GH.

Table 4. Studies investigating the effects of physical activities and exercise on growth hormone in elderly subjects.

\begin{tabular}{|c|c|c|c|c|c|c|}
\hline Authors & Study Year & Sample Size & Age & Gender & Intervention & Main findings \\
\hline Pyka et al. [107] & 1992 & $\begin{array}{c}11 \text { versus } 12 \\
\text { younger controls }\end{array}$ & $72 \pm 0.8 y$ & $\begin{array}{l}\text { Male }(\mathrm{n}=6) \\
\text { and female } \\
(\mathrm{n}=5)\end{array}$ & $\begin{array}{c}3 \text { sets of } 8 \text { repetitions for each } \\
\text { of the } 12 \text { exercises, at } 70 \% \text { of } \\
1 \text { RM values }\end{array}$ & $\begin{array}{c}\text { Growth hormone response to } \\
\text { resistance exercise } \\
\text { abolished/diminished in } \\
\text { elderly subjects }\end{array}$ \\
\hline $\begin{array}{c}\text { Cearlock and } \\
\text { Nuzzo [108] }\end{array}$ & 2001 & $\begin{array}{l}9 \text { versus } 16 \text { younger } \\
\text { controls }\end{array}$ & $60-85 y$ & Female & $\begin{array}{l}\text { 4-week exercise program } \\
\text { followed by } 1 \mathrm{w} \text { of no exercise }\end{array}$ & No changes \\
\hline $\begin{array}{l}\text { Banitalebi et al. } \\
\text { [74] }\end{array}$ & 2018 & $\begin{array}{l}40 \text { (12 of which } \\
\text { serving as controls) }\end{array}$ & $\begin{array}{c}67.35 \pm 1.40 \\
y\end{array}$ & Female & $\begin{array}{l}\text { Randomized allocation to a } \\
\text { resistance followed by } \\
\text { endurance training program } \\
(\mathrm{n}=12) \text {, endurance training } \\
\text { followed by resistance training } \\
(\mathrm{n}=12) \text {, interval } \\
\text { resistance-endurance training } \\
(\mathrm{n}=12) \text { groups }\end{array}$ & No changes \\
\hline
\end{tabular}

Abbreviations: RM (repetition maximum); w (week); y (years). 


\section{Glucagon, Aging and Physical Activity}

Glucagon is a peptide hormone, belonging to the secretin family of hormones, produced and released by the alpha cells of the pancreas. Being the major catabolic hormone of the human body, it increases blood glucose and fatty acids concentration, differently from insulin [109].

Of note, no studies investigated the effect of physical activity on glucagon concentration in elderly subjects, with the exception of Hagberg and coworkers [82], who found no changes in trained older subjects, whereas untrained individuals reported increases in glucagon levels.

\section{Cortisol, Aging and Physical Activity}

Cortisol, the primary stress hormone, is a steroid belonging to the glucocorticoid family, produced and released by the zona fasciculata of the adrenal cortex. This hormone plays a key role in controlling blood glucose and metabolism in general. Studies exploring the impact of age on cortisol have shown that cortisol increases with human aging. Seaton [110] reported that there was an elevation of night time cortisol levels in elderly individuals and this increase could be caused by stressful factors such as insomnia. Our laboratory has demonstrated that middle-aged men have higher basal cortisol concentrations than young men [111].

There are only a few studies that have examined the effect of exercise training on cortisol in elderly subjects. Herbert et al. [23] investigated the difference between lifelong sedentary and endurance-trained master athletes and observed no difference in basal cortisol. Moreover, when exposing sedentary individuals to an endurance training program of $150 \mathrm{~min} /$ week, there was no alteration to basal cortisol. Similarly, De Souza Vale et al. [112] investigated the effect of three months of water aerobics training in elderly women and reported no alteration to basal cortisol. However, an increase in cortisol following six-week HIIT in master athletes has been observed, with a concomitant increase in peak power output [23].

In middle-aged men, we have previously observed no alteration to basal cortisol following combined sprint and resistance training, however the acute cortisol response to a supramaximal sprint was elevated post-training [111].

Regarding the aging-related changes in the effect of exercise training on cortisol level, Kraemer et al. [113] compared the level of cortisol in young and older men after heavy resistance training three times per week for 10 weeks. Results showed a decline in resting cortisol at three and 10 weeks in the older group. However, Häkkinen et al. [114] reported that elderly subjects and middle-aged subjects did not experience any change in cortisol after six months' progressive resistance training. Similarly, Izquierdo et al. [115] investigated the effect of 16 weeks of progressive resistance training in older and middle-aged participants and observed no change in cortisol in the middle-aged group, but a decrease in the elderly group.

In summary, given the ambiguity of cortisol adaptation to resistance training, more research is required to determine the effect of training variables (duration, intensity, volume, frequency) and participant characteristics (age, training status, sex) on cortisol level.

\section{Cathecolamines, Aging and Physical Activity}

Catecholamine levels have been found to be different between young (20-years-old) and middle-aged men (40-years-old), with plasma noradrenaline concentrations being significantly lower $(p<0.05)$ in the young group when compared to the aged group. However, the precise neurobiological mechanisms leading to this difference in concentration levels are not very well-known and conflicting findings have been reported in the literature.

For instance, Hoeldtke et al. [116] showed that basal plasma noradrenaline concentration was greater in the elderly due to age-affected sympathetic nervous activity or sensitivity to sympatho-adrenal stimulation, without any difference in noradrenaline clearance. On the other hand, other authors found 
that clearance of noradrenaline tended to diminish with advancing age, which may contribute to the increased plasma concentrations observed.

Of note, no study has examined the effects of exercise training on catecholamines in older adults. In fact, the majority of studies investigated the impact of different types of training (sprint, endurance, resistance training) on catecholamine in young individuals [117-123]. Results were found to be at variance, and most of the time it was concluded that duration, intensity and type of training (aerobic and anaerobic) are the principal factors that induced alterations in catecholamine responses.

A notable exception was the investigation carried out by Poehlman and Danforth [71], who assessed the effects of 8 weeks of an endurance training program on norepinephrine kinetics in a sample of 19 older persons aged $64 \pm 1.6 \mathrm{yr}$. Resting concentrations of norepinephrine were found to be increased by $24 \%$ after cycling exercise due to a $21 \%$ increase in norepinephrine appearance rate, whereas no change in norepinephrine clearance could be detected.

As such, due to the dearth of data and information, future studies are needed to determine the effect of different exercise training modes and moderator variables on catecholamine secretion and catecholamine circulating concentration in older adults.

\section{Discussion and Future Prospects}

There is an increasing interest in exercise training, as a therapeutic lifestyle strategy to attenuate the hallmarks of aging and improve health. Exercise training attenuates many markers of biological aging and one of the underlying mechanisms may be through the promotion of a more 'youthful' endocrine profile. In vitro experiments suggest that cells treated with plasma isolated from younger individuals are healthier or more 'youthful' than those treated with plasma from their older peers. Therefore, in situ cells exposed to a youthful systemic environment will likely have improved functioning compared to those exposed to an older systemic environment. Evidence cited in this review suggests that it is possible that exercise can act as a countermeasure to endocrinological aging.

Regarding this last point, it is necessary to keep in mind that both similarities and differences in aging between/within genders exist.

However, despite such an increasing body of interest, the physiological effects of physical activity and exercise on glucoregulatory hormones in elderly subjects are relatively understudied. Evidence of the impact of training is generally circumstantial and randomized studies, carried out with high methodological rigor and quality are few or lacking for some hormones. Whereas insulin has captured the attention of scholars, there is a relative dearth of data and information for other hormones.

Given the importance of the topic of counter-aging effect of sports and physical activity and considering the epidemiological and clinical burden of aging and age-related disorders, more attention in the field is needed. Longitudinal studies employing larger sample sizes are warranted.

Author Contributions: Conceptualization, M.S. (Maha Sellami), N.L.B. and B.D.; methodology, M.S. (Maha Sellami) and N.L.B.; software, M.S. (Maha Sellami) and N.L.B.; validation, M.S. (Maha Sellami) and N.L.B.; formal analysis, M.S. (Maha Sellami) and N.L.B.; investigation, M.S. (Maha Sellami) and N.L.B.; resources, M.S. (Maha Sellami); data curation, M.S. (Maha Sellami) and N.L.B.; writing-original draft preparation, M.S. (Maha Sellami), N.L.B. and M.S. (Maamer Slimani); writing-review and editing, L.H., G.J., A.D.G. and B.D.; visualization, M.S. (Maha Sellami); supervision, M.S. (Maha Sellami); project administration, M.S. (Maha Sellami); funding acquisition, N.L.B.

Funding: This research received no external funding.

Conflicts of Interest: The authors declare no conflict of interest.

\section{References}

1. Watad, A.; Bragazzi, N.L.; Adawi, M.; Amital, H.; Toubi, E.; Porat, B.S.; Shoenfeld, Y. Autoimmunity in the Elderly: Insights from Basic Science and Clinics-A Mini-Review. Gerontology 2017, 63, 515-523. [CrossRef]

2. Harman, S.M.; Metter, E.J.; Tobin, J.D.; Pearson, J.; Blackman, M.R. Longitudinal effects of aging on serum total and free testosterone levels in healthy men. J. Clin. Endocrinol. Metab. 2001, 86, 724-731. [CrossRef] 
3. López-Otín, C.; Blasco, M.A.; Partridge, L.; Serrano, M.; Kroemer, G. The hallmarks of aging. Cell 2013, 153, 1194-1217. [CrossRef]

4. Fleg, J.L.; Lakatta, E.G. Role of muscle loss in the age-associated reduction in VO2max. J. Appl. Physiol. 1988, 65, 1147-1151. [CrossRef]

5. Frontera, W.R.; Hughes, V.A.; Lutz, K.J.; Evans, W.J. A cross-sectional study of muscle strength and mass in 45- to 78-yr-old men and women. J. Appl. Physiol. 1991, 71, 644-650. [CrossRef]

6. Gaitanos, G.C.; Williams, C.; Boobis, L.H.; Brooks, S. Human muscle metabolism during intermittent maximal exercise. J. Appl. Physiol. 1993, 75, 712-719. [CrossRef]

7. Evans, W.J. Effects of exercise on body composition and functional capacity of the elderly. J. Gerontol. A Biol. Sci. Med. Sci. 1995, 50, 147-150.

8. Korhonen, M.T.; Cristea, A.; Alén, M.; Hakkinen, K.; Sipila, S.; Mero, A.; Viitasalo, J.T.; Larsson, L.; Suominen, H. Aging, muscle fiber type, and contractile function in sprint-trained athletes. J. Appl. Physiol. 2006, 101, 906-917. [CrossRef]

9. Metter, E.J.; Conwit, R.; Tobin, J.; Fozard, J.L. Age-associated loss of power and strength in the upper extremities in women and men. J. Gerontol. A Biol. Sci. Med. Sci. 1997, 52, B267-B276. [CrossRef]

10. Augustin, H.; Adcott, J.; Elliott, C.J.H.; Partridge, L. Complex roles of myoglianin in regulating adult performance and lifespan. Fly (Austin) 2017, 11, 284-289. [CrossRef]

11. Elliott, B.T.; Herbert, P.; Sculthorpe, N.; Grace, F.M.; Stratton, D.; Hayes, L.D. Lifelong exercise, but not short-term high-intensity interval training, increases GDF11, a marker of successful aging: A preliminary investigation. Physiol. Rep. 2017, 5, e13343. [CrossRef]

12. Sakuma, K.; Yamaguchi, A. Sarcopenia and age-related endocrine function. Int. J. Endocrinol. 2012, 2012, 127362. [CrossRef]

13. Sipilä, S.; Narici, M.; Kjaer, M.; Pöllänen, E.; Atkinson, R.A.; Hansen, M.; Kovanen, V. Sex hormones and skeletal muscle weakness. Biogerontology 2013, 14, 231-245. [CrossRef]

14. Kalampouka, I.; van Bekhoven, A.; Elliott, B.T. Differing Effects of Younger and Older Human Plasma on C2C12 Myocytes in Vitro. Front. Physiol. 2018, 9, 152. [CrossRef]

15. Bean, J.F.; Vora, A.; Frontera, W.R. Benefits of exercise for community-dwelling older adults. Arch. Phys. Med. Rehabil. 2004, 85, 31-42. [CrossRef]

16. Covey, A.; Jokl, P. Qualitative Performance of the Aging Athlete. J. Med. Sci. Tennis 2009, 14, 5-15.

17. Galloway, M.T.; Jokl, P. Aging successfully: The importance of physical activity in maintaining health and function. J. Am. Acad. Orthop. Surg. 2000, 8, 37-44. [CrossRef]

18. Chu, C.H.; Chen, A.G.; Hung, T.M.; Wang, C.C.; Chang, Y.K. Exercise and fitness modulate cognitive function in older adults. Psychol. Aging 2015, 30, 842-848. [CrossRef]

19. Slimani, M.; Ramirez-Campillo, R.; Paravlic, A.; Hayes, L.D.; Bragazzi, N.L.; Sellami, M. The Effects of Physical Training on Quality of Life, Aerobic Capacity, and Cardiac Function in Older Patients with Heart Failure: A Meta-Analysis. Front. Physiol. 2018, 9, 1564. [CrossRef] [PubMed]

20. Galbo, H. Endocrinology and metabolism in exercise. Int. J. Sports Med. 1981, 2, 203-211. [CrossRef]

21. Hayes, L.D.; Herbert, P.; Sculthorpe, N.F.; Grace, F.M. Exercise training improves free testosterone in lifelong sedentary aging men. Endocr. Connect. 2017, 6, 306-310. [CrossRef]

22. Morganti, C.M.; Nelson, M.E.; Fiatarone, M.A.; Dallal, G.E.; Economos, C.D.; Crawford, B.M.; Evans, W.J. Strength improvements with 1 year of progressive resistance training in older women. Med. Sci. Exerc. 1995, 27, 906-912.

23. Herbert, P.; Hayes, L.D.; Sculthorpe, N.; Grace, F.M. High-intensity interval training (HIIT) increases insulin-like growth factor-I (IGF-I) in sedentary aging men but not masters' athletes: An observational study. Aging Male 2017, 20, 54-59. [CrossRef] [PubMed]

24. Sellami, M.; Ben Abderrahman, A.; Kebsi, W.; De Sousa, M.V.; Zouhal, H. Effect of sprint and strength training on glucoregulatory hormones: Effect of advanced age. Exp. Biol. Med. 2017, 242, 113-123. [CrossRef]

25. Zouhal, H.; Vincent, S.; Moussa, E.; Botcazou, M.; Delamarche, P.; Gratas-Delamarche, A. Early advancing age alters plasma glucose and glucoregulatory hormones in response to supramaximal exercise. J. Sci. Med. Sport 2009, 12, 652-656. [CrossRef] [PubMed]

26. Ronkainen, H.; Vakkuri, O.; Kauppila, A. Effects of physical exercise on the serum concentration of melatonin in female runners. Acta Obstetr. Gynecol. Scand. 1986, 65, 827-829. [CrossRef] 
27. Benelli, P.; Ditroilo, M.; Forte, R.; De Vito, G.; Stocchi, V. Assessment of post-competition peak blood lactate in male and female master swimmers aged 40-79 years and its relationship with swimming performance. Eur. J. Appl. Physiol. 2007, 99, 685-693. [CrossRef]

28. Morris, B.J.; Donlon, T.A.; He, Q.; Grove, J.S.; Masaki, K.H.; Elliott, A.; Willcox, D.C.; Willcox, B.J. Association analyses of insulin signaling pathway gene polymorphisms with healthy aging and longevity in Americans of Japanese ancestry. J. Gerontol. A Biol. Sci. Med. Sci. 2014, 69, 270-273. [CrossRef] [PubMed]

29. Kusy, K.; Zieliński, J. Aging, aerobic capacity and insulin sensitivity in masters athletes: Endurance and speed-power training benefits. Trends Sport Sci. 2014, 21, 73-84.

30. Chang, A.M.; Halter, J.B. Aging and insulin secretion. Am. J. Physiol.-Endocrinol. Metab. 2003, 284 , E7-E12. [CrossRef]

31. Heiskanen, M.A.; Leskinen, T.; Heinonen, I.H.; Löyttyniemi, E.; Eskelinen, J.J.; Virtanen, K.; Hannukainen, J.C.; Kalliokoski, K.K. Right ventricular metabolic adaptations to high-intensity interval and moderate-intensity continuous training in healthy middle-aged men. Am. J. Physiol. Heart Circ. Physiol. 2016, 311, H667-H675. [CrossRef] [PubMed]

32. Kirwan, J.P.; Kohrt, W.M.; Wojta, D.M.; Bourey, R.E.; Holloszy, J.O. Endurance exercise training reduces glucose-stimulated insulin levels in 60-to 70-year-old men and women. J. Gerontol 1993, 48, M84-M90. [CrossRef] [PubMed]

33. Seals, D.R.; Hagberg, J.M.; Hurley, B.F.; Ehsani, A.A.; Holloszy, J.O. Effects of endurance training on glucose tolerance and plasma lipid levels in older men and women. JAMA 1984, 252, 645-649. [CrossRef] [PubMed]

34. Kahn, S.E.; Larson, V.G.; Beard, J.C.; Cain, K.C.; Fellingham, G.W.; Schwartz, R.S.; Veith, R.C.; Stratton, J.R.; Cerqueira, M.D.; Abrass, I.B. Effect of exercise on insulin action, glucose tolerance, and insulin secretion in aging. Am. J. Physiol. 1990, 258, E937-E943. [CrossRef] [PubMed]

35. Evans, E.M.; Racette, S.B.; Peterson, L.R.; Villareal, D.T.; Greiwe, J.S.; Holloszy, J.O. Aerobic power and insulin action improve in response to endurance exercise training in healthy 77-87 yr olds. J. Appl. Physiol. 2005, 98, 40-45. [CrossRef] [PubMed]

36. Goulet, E.D.; Mélançon, M.O.; Aubertin-Leheudre, M.; Dionne, I.J. Aerobic training improves insulin sensitivity 72-120 h after the last exercise session in younger but not in older women. Eur. J. Appl. Physiol. 2005, 95, 146-152. [CrossRef] [PubMed]

37. Dipietro, L.; Yeckel, C.W.; Dziura, J. Progressive improvement in glucose tolerance following lower-intensity resistance versus moderate-intensity aerobic training in older women. J. Phys. Act. Health 2008, 5, 854-869. [CrossRef] [PubMed]

38. Ihalainen, J.K.; Inglis, A.; Mäkinen, T.; Newton, R.U.; Kainulainen, H.; Kyröläinen, H.; Walker, S. Strength Training Improves Metabolic Health Markers in Older Individual Regardless of Training Frequency. Front. Physiol. 2019, 10, 32. [CrossRef] [PubMed]

39. Guezennec, C.Y.; Giaoui, M.; Voignier, J.P.; Legrand, H.; Fournier, E. Evolution of plasma levels of LDH (lactate dehydrogenase), CPK (creatine phosphokinase) and myoglobin at the end of a $100 \mathrm{~km}$ race and a triathlon. Sci. Sports 1986, 1, 255-263. [CrossRef]

40. Guezennec, Y.; Leger, L.; Lhoste, F.; Aymonod, M.; Pesquies, P.C. Hormone and metabolite response to weight-lifting training sessions. Int. J. Sports Med. 1986, 7, 100-105. [CrossRef]

41. Holten, M.K.; Zacho, M.; Gaster, M.; Juel, C.; Wojtaszewski, J.F.; Dela, F. Strength training increases insulin-mediated glucose uptake, GLUT4 content, and insulin signaling in skeletal muscle in patients with type 2 diabetes. Diabetes 2004, 53, 294-305. [CrossRef] [PubMed]

42. Craig, B.W.; Everhart, J.; Brown, R. The influence of high-resistance training on glucose tolerance in young and elderly subjects. Mech. Aging Dev. 1989, 49, 147-157. [CrossRef]

43. Sellami, M.; Dhahbi, W.; Hayes, L.D.; Padulo, J.; Rhibi, F.; Djemail, H.; Chaouachi, A. Combined sprint and resistance training abrogates age differences in somatotropic hormones. PLoS ONE 2017, 12, e0183184. [CrossRef] [PubMed]

44. Sailani, M.R.; Halling, J.F.; Møller, H.D.; Lee, H.; Plomgaard, P.; Pilegaard, H.; Snyder, M.P.; Regenberg, B. Lifelong physical activity is associated with promoter hypomethylation of genes involved in metabolism, myogenesis, contractile properties and oxidative stress resistance in aged human skeletal muscle. Sci. Rep. 2019, 9, 3272. [CrossRef] [PubMed] 
45. Sharples, A.P.; Stewart, C.E.; Seaborne, R.A. Does skeletal muscle have an 'epi'-memory? The role of epigenetics in nutritional programming, metabolic disease, aging and exercise. Aging Cell 2016, 15, 603-616. [CrossRef]

46. Prior, S.J.; Goldberg, A.P.; Ortmeyer, H.K.; Chin, E.R.; Chen, D.; Blumenthal, J.B.; Ryan, A.S. Increased Skeletal Muscle Capillarization Independently Enhances Insulin Sensitivity in Older Adults After Exercise Training and Detraining. Diabetes 2015, 64, 3386-3395. [CrossRef]

47. Hildebrandt, W.; Schwarzbach, H.; Pardun, A.; Hannemann, L.; Bogs, B.; König, A.M.; Mahnken, A.H.; Hildebrandt, O.; Koehler, U.; Kinscherf, R. Age-related differences in skeletal muscle microvascular response to exercise as detected by contrast-enhanced ultrasound (CEUS). PLoS ONE 2017, 12, e0172771. [CrossRef]

48. Richter, E.A.; Hargreaves, M. Exercise, GLUT4, and skeletal muscle glucose uptake. Physiol. Rev. 2013, 93, 993-1017. [CrossRef]

49. Distefano, G.; Goodpaster, B.H. Effects of Exercise and Aging on Skeletal Muscle. Cold Spring Harb. Perspect. Med. 2018, 8, a029785. [CrossRef] [PubMed]

50. Bayol, S.A.; Bruce, C.R.; Wadley, G.D. Growing healthy muscles to optimise metabolic health into adult life. J. Dev. Orig. Health Dis. 2014, 5, 420-434. [CrossRef]

51. Ryan, A.S. Insulin resistance with aging: Effects of diet and exercise. Sports Med. 2000, 30, 327-346. [CrossRef] [PubMed]

52. Santos-Parker, J.R.; Santos-Parker, K.S.; McQueen, M.B.; Martens, C.R.; Seals, D.R. Habitual aerobic exercise and circulating proteomic patterns in healthy adults: Relation to indicators of healthspan. J. Appl. Physiol. 2018, 125, 1646-1659. [CrossRef]

53. Lithgow, H.M.; Leggate, M. The Effect of a Single Bout of High Intensity Intermittent Exercise on Glucose Tolerance in Non-diabetic Older Adults. Int. J. Exerc. Sci. 2018, 11, 95-105. [PubMed]

54. Chadan, S.G.; Dill, R.P.; Vanderhoek, K.; Parkhouse, W.S. Influence of physical activity on plasma insulin-like growth factor-1 and insulin-like growth factor binding proteins in healthy older women. Mech. Ageing Dev. 1999, 109, 21-34. [CrossRef]

55. Fujita, S.; Rasmussen, B.B.; Cadenas, J.G.; Drummond, M.J.; Glynn, E.L.; Sattler, F.R.; Volpi, E. Aerobic exercise overcomes the age-related insulin resistance of muscle protein metabolism by improving endothelial function and Akt/mammalian target of rapamycin signaling. Diabetes 2007, 56, 1615-1622. [CrossRef] [PubMed]

56. Kodama, S.; Shu, M.; Saito, K.; Murakami, H.; Tanaka, K.; Kuno, S.; Ajisaka, R.; Sone, Y.; Onitake, F.; Takahashi, A.; Shimano, H.; Kondo, K.; Yamada, N.; Sone, H. Even low-intensity and low-volume exercise training may improve insulin resistance in the elderly. Intern. Med. 2007, 46, 1071-1077. [CrossRef] [PubMed]

57. Lira, F.S.; Pimentel, G.D.; Santos, R.V.; Oyama, L.M.; Damaso, A.R.; Oller do Nascimento, C.M.; Viana, V.A.; Boscolo, R.A.; Grassmann, V.; Santana, M.G.; Esteves, A.M.; Tufik, S.; de Mello, M.T. Exercise training improves sleep pattern and metabolic profile in elderly people in a time-dependent manner. Lipids Health Dis. 2011, 10, 1-6. [CrossRef]

58. McGregor, D.E.; Carson, V.; Palarea-Albaladejo, J.; Dall, P.M.; Tremblay, M.S.; Chastin, S.F.M. Compositional Analysis of the Associations between 24-h Movement Behaviours and Health Indicators among Adults and Older Adults from the Canadian Health Measure Survey. Int. J. Environ. Res. Public Health 2018, 15, 1779. [CrossRef] [PubMed]

59. Gando, Y.; Murakami, H.; Kawakami, R.; Tanaka, N.; Sanada, K.; Tabata, I.; Higuchi, M.; Miyachi, M. Light-intensity physical activity is associated with insulin resistance in elderly Japanese women independent of moderate-to vigorous-intensity physical activity. J. Phys. Act. Health 2014, 11, 266-271. [CrossRef] [PubMed]

60. DiPietro, L.; Seeman, T.E.; Stachenfeld, N.S.; Katz, L.D.; Nadel, E.R. Moderate-intensity aerobic training improves glucose tolerance in aging independent of abdominal adiposity. J. Am. Geriatr. Soc. 1998, 46, 875-879. [CrossRef] [PubMed]

61. Seals, D.R.; Hagberg, J.M.; Allen, W.K.; Hurley, B.F.; Dalsky, G.P.; Ehsani, A.A.; Holloszy, J.O. Glucose tolerance in young and older athletes and sedentary men. J. Appl. Physiol. Respir. Environ. Exerc. Physiol. 1984, 56, 1521-1525. [CrossRef] [PubMed]

62. Hollenbeck, C.B.; Haskell, W.; Rosenthal, M.; Reaven, G.M. Effect of habitual physical activity on regulation of insulin-stimulated glucose disposal in older males. J. Am. Geriatr. Soc. 1985, 33, 273-277. [CrossRef]

63. Broughton, D.L.; James, O.W.; Alberti, K.G.; Taylor, R. Peripheral and hepatic insulin sensitivity in healthy elderly human subjects. Eur. J. Clin. Investig. 1991, 21, 13-21. [CrossRef] 
64. Mikkelsen, U.R.; Couppé, C.; Karlsen, A.; Grosset, J.F.; Schjerling, P.; Mackey, A.L.; Klausen, H.H.; Magnusson, S.P.; Kjær, M. Life-long endurance exercise in humans: Circulating levels of inflammatory markers and leg muscle size. Mech. Ageing Dev. 2013, 134, 531-540. [CrossRef] [PubMed]

65. Park, J.M.; Dong, J.J.; Lee, J.W.; Shim, J.Y.; Lee, Y.J. The relationship between employment status and insulin resistance in the Korean elderly population. Aging Clin. Exp. Res. 2018, 30, 1385-1390. [CrossRef] [PubMed]

66. DiPietro, L.; Dziura, J.; Yeckel, C.W.; Neufer, P.D. Exercise and improved insulin sensitivity in older women: Evidence of the enduring benefits of higher intensity training. J. Appl. Physiol. 2006, 100, 142-149. [CrossRef] [PubMed]

67. Hwang, C.L.; Yoo, J.K.; Kim, H.K.; Hwang, M.H.; Handberg, E.M.; Petersen, J.W.; Christou, D.D. Novel all-extremity high-intensity interval training improves aerobic fitness, cardiac function and insulin resistance in healthy older adults. Exp. Gerontol. 2016, 82, 112-119. [CrossRef] [PubMed]

68. Chen, T.C.; Tseng, W.C.; Huang, G.L.; Chen, H.L.; Tseng, K.W.; Nosaka, K. Superior Effects of Eccentric to Concentric Knee Extensor Resistance Training on Physical Fitness, Insulin Sensitivity and Lipid Profiles of Elderly Men. Front. Physiol. 2017, 8, 209. [CrossRef] [PubMed]

69. García-Hermoso, A.; Martínez-Vizcaíno, V.; Sánchez-López, M.; Recio-Rodriguez, J.I.; Gómez-Marcos, M.A.; García-Ortiz, L.; EVIDENT Group. Moderate-to-vigorous physical activity as a mediator between sedentary behavior and cardiometabolic risk in Spanish healthy adults: A mediation analysis. Int. J. Behav. Nutr. Phys. Act. 2015, 12, 78. [CrossRef]

70. Tonino, R.P. Effect of physical training on the insulin resistance of aging. Am. J. Physiol. 1989, 256, E352-E356. [CrossRef] [PubMed]

71. Poehlman, E.T.; Danforth, E., Jr. Endurance training increases metabolic rate and norepinephrine appearance rate in older individuals. Am. J. Physiol. 1991, 261, E233-E239. [CrossRef]

72. Dela, F.; Niederseer, D.; Patsch, W.; Pirich, C.; Müller, E.; Niebauer, J. Glucose homeostasis and cardiovascular disease biomarkers in older alpine skiers. Scand. J. Med. Sci. Sports 2011, 21 (Suppl. 1), 56-61. [CrossRef] [PubMed]

73. Robinson, M.M.; Dasari, S.; Konopka, A.R.; Johnson, M.L.; Manjunatha, S.; Esponda, R.R.; Carter, R.E.; Lanza, I.R.; Nair, K.S. Enhanced Protein Translation Underlies Improved Metabolic and Physical Adaptations to Different Exercise Training Modes in Young and Old Humans. Cell Metab. 2017, 25, 581-592. [CrossRef] [PubMed]

74. Banitalebi, E.; Faramarzi, M.; Bagheri, L.; Kazemi, A.R. Comparison of performing 12 weeks' resistance training before, after and/or in between aerobic exercise on the hormonal status of aged women: A randomized controlled trial. Horm. Mol. Biol. Clin. Investig. 2018, 35. [CrossRef] [PubMed]

75. Cononie, C.C.; Goldberg, A.P.; Rogus, E.; Hagberg, J.M. Seven consecutive days of exercise lowers plasma insulin responses to an oral glucose challenge in sedentary elderly. J. Am. Geriatr. Soc. 1994, 42, 394-398. [CrossRef] [PubMed]

76. Bassami, M.; Ahmadizad, S.; Doran, D.; MacLaren, D.P. Effects of exercise intensity and duration on fat metabolism in trained and untrained older males. Eur. J. Appl. Physiol. 2007, 101, 525-532. [CrossRef] [PubMed]

77. Søgaard, D.; Lund, M.T.; Scheuer, C.M.; Dehlbaek, M.S.; Dideriksen, S.G.; Abildskov, C.V.; Christensen, K.K.; Dohlmann, T.L.; Larsen, S.; Vigelsø, A.H.; Dela, F.; Helge, J.W. High-intensity interval training improves insulin sensitivity in older individuals. Acta Physiol. 2018, 222, e13009. [CrossRef] [PubMed]

78. Conn, V.S.; Koopman, R.J.; Ruppar, T.M.; Phillips, L.J.; Mehr, D.R.; Hafdahl, A.R. Insulin Sensitivity Following Exercise Interventions: Systematic Review and Meta-Analysis of Outcomes Among Healthy Adults. J. Prim. Care Community Health 2014, 5, 211-222. [CrossRef] [PubMed]

79. Poehlman, E.T.; Dvorak, R.V.; DeNino, W.F.; Brochu, M.; Ades, P.A. Effects of resistance training and endurance training on insulin sensitivity in nonobese, young women: A controlled randomized trial. J. Clin. Endocrinol. Metab. 2000, 85, 2463-2468. [CrossRef] [PubMed]

80. Parkhouse, W.S.; Coupland, D.C.; Li, C.; Vanderhoek, K.J. IGF-1 bioavailability is increased by resistance training in older women with low bone mineral density. Mech. Aging Dev. 2000, 113, 75-83. [CrossRef]

81. Arnarson, A.; Gudny Geirsdottir, O.; Ramel, A.; Jonsson, P.V.; Thorsdottir, I. Insulin-Like Growth Factor-1 and Resistance Exercise in Community Dwelling Old Adults. J. Nutr. Health Aging 2015, 19, 856-860. [CrossRef] [PubMed] 
82. Hagberg, J.M.; Seals, D.R.; Yerg, J.E.; Gavin, J.; Gingerich, R.; Premachandra, B.; Holloszy, J.O. Metabolic responses to exercise in young and older athletes and sedentary men. J. Appl. Physiol. 1988, 65, 900-908. [CrossRef] [PubMed]

83. Poehlman, E.T.; Copeland, K.C. Influence of physical activity on insulin-like growth factor-I in healthy younger and older men. J. Clin. Endocrinol. Metab. 1990, 71, 1468-1473. [CrossRef] [PubMed]

84. Poehlman, E.T.; Rosen, C.J.; Copeland, K.C. The influence of endurance training on insulin-like growth factor-1 in older individuals. Metabolism 1994, 43, 1401-1405. [CrossRef]

85. Vitiello, M.V.; Wilkinson, C.W.; Merriam, G.R.; Moe, K.E.; Prinz, P.N.; Ralph, D.D.; Colasurdo, E.A.; Schwartz, R.S. Successful 6-month endurance training does not alter insulin-like growth factor-I in healthy older men and women. J. Gerontol. A Biol. Sci. Med. Sci. 1997, 52, M149-M154. [CrossRef] [PubMed]

86. Bermon, S.; Ferrari, P.; Bernard, P.; Altare, S.; Dolisi, C. Responses of total and free insulin-like growth factor-I and insulin-like growth factor binding protein-3 after resistance exercise and training in elderly subjects. Acta Physiol. Scand. 1999, 165, 51-56. [CrossRef]

87. Bonnefoy, M.; Kostka, T.; Patricot, M.C.; Berthouze, S.E.; Mathian, B.; Lacour, J.R. Influence of acute and chronic exercise on insulin-like growth factor-I in healthy active elderly men and women. Aging 1999, 11, 373-379. [CrossRef]

88. Ravaglia, G.; Forti, P.; Maioli, F.; Pratelli, L.; Vettori, C.; Bastagli, L.; Mariani, E.; Facchini, A.; Cucinotta, D. Regular moderate intensity physical activity and blood concentrations of endogenous anabolic hormones and thyroid hormones in aging men. Mech. Ageing Dev. 2001, 122, 191-203. [CrossRef]

89. Borst, S.E.; Vincent, K.R.; Lowenthal, D.T.; Braith, R.W. Effects of resistance training on insulin-like growth factor and its binding proteins in men and women aged 60 to 85. J. Am. Geriatr. Soc. 2002, 50, 884-888. [CrossRef]

90. Dennis, R.A.; Przybyla, B.; Gurley, C.; Kortebein, P.M.; Simpson, P.; Sullivan, D.H.; Peterson, C.A. Aging alters gene expression of growth and remodeling factors in human skeletal muscle both at rest and in response to acute resistance exercise. Physiol. Genomics 2008, 32, 393-400. [CrossRef]

91. Tsai, C.L.; Wang, C.H.; Pan, C.Y.; Chen, F.C. The effects of long-term resistance exercise on the relationship between neurocognitive performance and GH, IGF-1, and homocysteine levels in the elderly. Front. Behav. Neurosci. 2015, 9, 23. [CrossRef] [PubMed]

92. Maass, A.; Düzel, S.; Brigadski, T.; Goerke, M.; Becke, A.; Sobieray, U.; Neumann, K.; Lövdén, M.; Lindenberger, U.; Bäckman, L.; Braun-Dullaeus, R.; Ahrens, D.; Heinze, H.J.; Müller, N.G.; Lessmann, V.; Sendtner, M.; Düzel, E. Relationships of peripheral IGF-1, VEGF and BDNF levels to exercise-related changes in memory, hippocampal perfusion and volumes in older adults. Neuroimage 2016, 131, 142-154. [CrossRef] [PubMed]

93. De Gonzalo-Calvo, D.; Fernández-García, B.; de Luxán-Delgado, B.; Rodríguez-González, S.; García-Macia, M.; Suárez, F.M.; Solano, J.J.; Rodríguez-Colunga, M.J.; Coto-Montes, A. Long-term training induces a healthy inflammatory and endocrine emergent biomarker profile in elderly men. Age 2012, 34, 761-771. [CrossRef] [PubMed]

94. Negaresh, R.; Ranjbar, R.; Habibi, A.; Mokhtarzade, M.; Fokin, A.; Gharibvand, M.M. The effect of resistance training on quadriceps muscle volume and some growth factors in elderly and young men. Adv. Gerontol. 2017, 30, 880-887. [PubMed]

95. Yoon, S.J.; Lee, M.J.; Lee, H.M.; Lee, J.S. Effect of low-intensity resistance training with heat stress on the HSP72, anabolic hormones, muscle size, and strength in elderly women. Aging Clin. Exp. Res. 2017, 29, 977-984. [CrossRef] [PubMed]

96. Cunha, P.M.; Nunes, J.P.; Tomeleri, C.M.; Nascimento, M.A.; Schoenfeld, B.J.; Antunes, M.; Gobbo, L.A.; Teixeira, D.; Cyrino, E.S. Resistance Training Performed with Single and Multiple Sets Induces Similar Improvements in Muscular Strength, Muscle Mass, Muscle Quality, and IGF-1 in Older Women: A Randomized Controlled Trial. J. Strength Cond. Res. 2018, in press. [CrossRef] [PubMed]

97. Negaresh, R.; Ranjbar, R.; Baker, J.S.; Habibi, A.; Mokhtarzade, M.; Gharibvand, M.M.; Fokin, A. Skeletal Muscle Hypertrophy, Insulin-like Growth Factor 1, Myostatin and Follistatin in Healthy and Sarcopenic Elderly Men: The Effect of Whole-body Resistance Training. Int. J. Prev. Med. 2019, 10, 29.

98. Saghiv, M.S.; Sira, D.B.; Goldhammer, E.; Sagiv, M. The effects of aerobic and anaerobic exercises on circulating soluble-Klotho and IGF-I in young and elderly adults and in CAD patients. J. Circ. Biomark. 2017, 6. [CrossRef] 
99. Hand, B.D.; Kostek, M.C.; Ferrell, R.E.; Delmonico, M.J.; Douglass, L.W.; Roth, S.M.; Hagberg, J.M.; Hurley, B.F. Influence of promoter region variants of insulin-like growth factor pathway genes on the strength-training response of muscle phenotypes in older adults. J. Appl. Physiol. 2007, 103, 1678-1687. [CrossRef]

100. Sattler, F.R. Growth hormone in the aging male. Best Pract. Res. Clin. Endocrinol. Metab. 2013, 27, 541-555. [CrossRef]

101. Veldhuis, J.D.; Liem, A.Y.; South, S.; Weltman, A.; Weltman, J.; Clemmons, D.A.; Abbott, R.; Mulligan, T.; Johnson, M.L.; Pincus, S. Differential impact of age, sex steroid hormones, and obesity on basal vs. pulsatile growth hormone secretion in men as assessed in an ultrasensitive chemiluminescence assay. J. Clin. Endocrinol. Metab. 1995, 80, 3209-3222. [PubMed]

102. Khan, A.S.; Sane, D.C.; Wannenburg, T.; Sonntag, W.E. Growth hormone, insulin-like growth factor-1 and the aging cardiovascular system. Cardiovasc. Res. 2002, 54, 25-35. [CrossRef]

103. Martinez-Moreno, C.G.; Fleming, T.; Carranza, M.; Ávila-Mendoza, J.; Luna, M.; Harvey, S.; Arámburo, C. Growth hormone protects against kainate excitotoxicity and induces BDNF and NT3 expression in chicken neuroretinal cells. Exp. Eye Res. 2018, 166, 1-12. [CrossRef] [PubMed]

104. Sanders, E.J.; Parker, E.; Harvey, S. Growth hormone-mediated survival of embryonic retinal ganglion cells: Signaling mechanisms. Gen. Comp. Endocrinol. 2008, 156, 613-621. [CrossRef]

105. Deuschle, M.; Blum, W.F.; Frystyk, J.; Ørskov, H.; Schweiger, U.; Weber, B.; Körner, A.; Gotthardt, U.; Schmider, J.; Standhardt, H.; Heuser, I. Endurance training and its effect upon the activity of the GH-IGFs system in the elderly. Int. J. Sports Med. 1998, 19, 250-254. [CrossRef]

106. Vanhelder, W.; Radomski, M.W.; Goode, R.C. Growth hormone responses during intermittent weight lifting exercise in men. Eur. J. Appl. Physiol. Occup. Physiol. 1984, 53, 31-34. [CrossRef] [PubMed]

107. Pyka, G.; Wiswell, R.A.; Marcus, R. Age-dependent effect of resistance exercise on growth hormone secretion in people. J. Clin. Endocrinol. Metab. 1992, 75, 404-407.

108. Cearlock, D.M.; Nuzzo, N.A. Effects of sustained moderate exercise on cholesterol, growth hormone and cortisol blood levels in three age groups of women. Clin. Lab. Sci. 2001, 14, 108-111.

109. Jones, B.J.; Tan, T.; Bloom, S.R. Minireview: Glucagon in stress and energy homeostasis. Endocrinology 2012, 153, 1049-1054. [CrossRef]

110. Seaton, K. Cortisol: The aging hormone, the stupid hormone. J. Natl. Med. Assoc. 1995, 87, 667.

111. Sellami, M.; Dhahbi, W.; Hayes, L.D.; Kuvacic, G.; Milic, M.; Padulo, J. The effect of acute and chronic exercise on steroid hormone fluctuations in young and middle-aged men. Steroids 2018, 132, 18-24. [CrossRef]

112. De Souza Vale, R.G.; de Oliveira, R.D.; Pernambuco, C.S.; da Silva Novaes, J.; de Andrade, A.D.F.D. Effects of muscle strength and aerobic training on basal serum levels of IGF-1 and cortisol in elderly women. Arch. Gerontol. Geriatr. 2009, 49, 343-347. [CrossRef] [PubMed]

113. Kraemer, W.J.; Fleck, S.J.; Maresh, C.M.; Ratamess, N.A.; Gordon, S.E.; Goetz, K.L.; Harman, E.A.; Frykman, P.N.; Volek, J.S.; Mazzetti, S.A.; Fry, A.C.; Marchitelli, L.J.; Patton, J.F. Acute hormonal responses to a single bout of heavy resistance exercise in trained power lifters and untrained men. Can. J. Appl. Physiol. 1999, 24, 524-537. [CrossRef] [PubMed]

114. Häkkinen, K.; Pakarinen, A.; Kraemer, W.J.; Newton, R.U.; Alen, M. Basal concentrations and acute responses of serum hormones and strength development during heavy resistance training in middle-aged and elderly men and women. J. Gerontol. A Biol. Sci. Med. Sci. 2000, 55, B95-B105. [PubMed]

115. Izquierdo, M.; Häkkinen, K.; Ibañez, J.; Garrues, M.; Antón, A.; Zuñiga, A.; Larrión, J.L.; Gorostiaga, E.M. Effects of strength training on muscle power and serum hormones in middle-aged and older men. J. Appl. Physiol. 2001, 90, 1497-1507. [CrossRef]

116. Hoeldtke, R.D.; Cilmi, K.M. Effects of aging on catecholamine metabolism. J. Clin. Endocrinol. Metab. 1985, 60, 479-484. [CrossRef] [PubMed]

117. Lacour, J.R.; Pequignot, J.M.; Geyssant, A.; Coudert, J.; Peyrin, L. Effect of training on plasma levels of catecholamines on the course of submaximal exercise. J. Physiol. 1983, 78, 838-842.

118. Winder, W.W.; Hagberg, J.M.; Hickson, R.C.; Ehsani, A.A.; McLane, J.A. Time course of sympathoadrenal adaptation to endurance exercise training in man. J. Appl. Physiol. 1978, 45, 370-374. [CrossRef] [PubMed]

119. Winder, W.W.; Hickson, R.C.; Hagberg, J.M.; Ehsani, A.A.; McLane, J.A. Training-induced changes in hormonal and metabolic responses to submaximal exercise. J. Appl. Physiol. 1979, 46, 766-771. [CrossRef] [PubMed] 
120. Zouhal, H.; Jacob, C.; Delamarche, P.; Gratas-Delamarche, A. Catecholamines and the effects of exercise, training and gender. Sports Med. 2008, 38, 401-423. [CrossRef]

121. Zouhal, H.; Jacob, C.; Rannou, F.; Gratas-Delamarche, A. Effect of training status on the sympathoadrenal activity during a supramaximal exercise in human. J. Sports Med. Phys. Fitness 2001, 41, 330. [PubMed]

122. Zouhal, H.; Gratas-Delamarche, A.; Rannou, F.; Granier, P.; Bentue-Ferrer, D.; Delamarche, P. Between 21 and 34 Years of Age, Aging Alters the Catecholamine Responses to Supramaximal Exercise in Endurance Trained Athletes. Int. J. Sports Med. 1999, 20, 343-348. [CrossRef] [PubMed]

123. Zouhal, H.; Lemoine, S.; Mathieu, M.E.; Casazza, G.A.; Jabbour, G. Catecholamines and Obesity: Effects of Exercise and Training. Sports Med. 2013, 43, 591-600. [CrossRef] [PubMed]

(C) 2019 by the authors. Licensee MDPI, Basel, Switzerland. This article is an open access article distributed under the terms and conditions of the Creative Commons Attribution (CC BY) license (http://creativecommons.org/licenses/by/4.0/). 